\title{
KONFLIK SOSIAL DAN EKONOMI SEBAGAI DAMPAK UNDANG - UNDANG NOMOR 6 TAHUN 2014 TENTANG DESA
}

\author{
Martinus Aditya Pardiyanto \\ Dosen Pancasila Fakultas Ekonomi Universitas Semarang
}

\begin{abstract}
ABSTRAK
Dengan ditetapkannya Undang-undang Nomor 6 Tahun 2014 Tentang Desa pada 15 Januari 2014 dapat memberi ruang bagi Pemerintahan Desa. Dikarenakan Kesejahteraan dan kemakmuran ekonomi rakyat tidak selamanya berada dilingkungan perkotaan saja, tetapi dalam membangun Indonesia haruslah di mulai dari Desa. Permasalahan yang dibahas didalam tesis ini (1). Siapakah aktoraktor yang diuntungkan di balik Undang-undang Nomor 6 Tahun 2014 Tentang Desa. (2). Potensi konflik apakah yang dimungkinkan timbul dengan ditetapkannya Undang-undang Nomor 6 Tahun 2014 Tentang Desa. Berdasarkan hasil penelitian dan pembahasan dapat dijelaskan bahwa: Kelompok Kepentingan, Politisi Dan Partai Politik, Kelompok kepentingan memainkan peran penting dalam pembentukan kebijakan, selain kelompok kepentingan, para politisi menggunakan partai politik untuk meraih kekuasaan. Serta Pemerintahan Desa, Luasnya kewenangan pemerintah desa tanpa pengawasan kuat Badan Permusyawaratan Desa pada akhirnya membuka peluang korupsi di desa disebabkan sumber daya aparatur yang minim, apalagi jika pemerintah lalai dalam melakukan pembinaan dan pengawasan sebagaimana amanat undang-undang desa. Potensi konflik yang dimungkinkan timbul, Undang-undang Nomor 6 Tahun 2014 Tentang Desa akan melahirkan konflik baru bagi sebagian masyarakat yang ada di desa, baik konflik manifes maupun konflik laten. Saran Sebuah perubahan menjadi desa mandiri jangan disalah artikan bahwa Pemerintah lainnya menjadi tidak bertanggungjawab untuk kelangsungan atas penyelenggaraan pemerintahan desa malah seharusnya pemerintah pusat mendorong dan membangkitkan semangat bagi pemerintah desa untuk maju dan bangkit serta berbenah diri sehingga wajah pemerintahan desa memang dapat menjadi citra pemerintahan lainnya dimata masyarakat.
\end{abstract}

Kata Kunci: Dampak, Desa, Konflik. 


\title{
SOCIAL AND ECONOMIC CONFLICTS AS THE IMPACT OF THE LAW NUMBER 6 OF 2014 ON VILLAGE
}

\author{
Martinus Aditya Pardiyanto \\ Lecturer of Pancasila, Faculty of Economics, University of Semarang
}

\begin{abstract}
With the enactment of Law Number 6 Year 2014 on the Village on January 15, 2014 can make space for the Village Government. Since welfare and economic prosperity of the people are not always located in urban area, building Indonesia begins from the village. The problems discussed in this thesis are (1). Who are the beneficiaries behind Law No. 6 of 2014 on Villages (2). What are the potential conflicts that exist in accordance with the stipulation of Law No. 6 of 2014 about the Village? Based on the results of research and discussions, it can be explained: Interest Groups, Politicians and Political Parties, Interest groups play an important role in the formation of policies, in addition to interest groups, politicians use political parties to gain power, as well as Village Government. The extent of village government regulations without strong supervision from the Village Deliberative Council ultimately opens opportunities for corruption in the village due to the lack of personnel resources, especially if the government is negligent in conducting guidance and supervision over the mandate of the village law. Potential conflicts that arise, Law Number 6 Year 2014 about the Village will give birth to new conflicts for some communities in the village, both manifest conflict and latent conflict. Suggestions a change to become an independent village should not be misunderstood, that other government levels become irresponsible for the operation of the governance of the village. Furthermore, the center government encourages and pushes spirit for the village government to advance and rise and clean up themselves, so that the village administration can indeed be the image of other government in the eyes of society.
\end{abstract}

Keywords: Impact, Village, Conflict. 


\section{PENDAHULUAN}

Dengan ditetapkannya Undangundang Nomor 6 Tahun 2014 Tentang Desa pada 15 Januari 2014 yang ditandatangani oleh Presiden Susilo Bambang Yudhoyono (SBY) dapat memberi ruang bagi Pemerintahan Desa. Pembangunan dapat mengubah cara pandang pembangunan Desa dan memafaatkan Sumber Daya Desa yang ada dengan kewenangan yang dimilikinya. Kesejahteraan dan kemakmuran ekomoni rakyat tidak selamanya berada dilingkungan perkotaan saja, tetapi dalam membangun Indonesia haruslah di mulai dari Desa. Desa merupakan bagian paling utama dalam sektor pembangunan yang berasal dari prakarsa rakyat Indonesia, guna mencapai kesejahteraan dan kemakmuran sekaligus berkeadilan dan berkesinambungan didaerah. Desa juga diharapkan menjadi daya tarik dalam meningkatkan pembangunan ekonomi rakyat sehingga akan berdampak meningkatnya kesejahteraan rakyat.

Pengaturan Tentang Desa didasarkan pada amanat Undang-Undang Dasar 1945 Pasal 18 B Ayat (2) yang berbunyi "Negara mengakui dan menghormati kesatuan-kesatuan masyarakat hukum adat beserta hak-hak tradisionalnya sepanjang masih hidup dan sesuai dengan perkembangan masyarakat dan prinsip Negara Kesatuan Republik Indonesia, yang diatur dalam undangundang".

Undang-undang ini disusun dengan semangat penerapan amanat konstitusi, yaitu pengaturan masyarakat hukum adat sesuai dengan ketentuan Pasal 18B ayat (2) dan Pasal 18 ayat (7), dengan konstruksi menggabungkan fungsi self governing community dengan local self government, sedemikian rupa, sehingga landasan konstitusional ini akan menjadi dasar yang kokoh bagi masa depan desa di Indonesia. Membangun Desa Membangun Negara. ${ }^{1}$

Adapun tujuan dari disahkannya Undang-undang Desa ini antara lain:

1. Memberikan pengakuan dan penghormatan atas desa yang sudah ada dengan keberagamannya sebelum dan sesudah terbentuknya Negara Kesatuan Republik Indonesia;

2. Memberikan kejelasan status dan kepastian hukum atas desa dalam sistem ketatanegaraan Republik Indonesia demi mewujudkan keadilan bagi seluruh rakyat Indonesia;

\footnotetext{
1 Yan Herizal. Makalah : Seminar Desa. www.forumwacana.lk.ipb.ac.id Mei 2014 Diakses pada tanggal 12 November 2014.
} 
3. Melestarikan dan memajukan adat, tradisi, dan budaya masyarakat desa;

4. Mendorong prakarsa, gerakan, dan partisipasi masyarakat desa untuk pengembangan potensi dan aset desa guna kesejahteraan bersama;

5. Membentuk pemerintahan desa yang profesional, efisien dan efektif, terbuka, serta bertanggung jawab;

6. Meningkatkan pelayanan publik bagi warga masyarakat desa guna mempercepat perwujudan kesejahteraan umum;

7. Meningkatkan ketahanan sosial budaya masyarakat desa guna mewujudkan masyarakat desa yang mampu memelihara kesatuan sosial sebagai bagian dari ketahanan nasional;

8. Memajukan perekonomian masyarakat desa serta mengatasi kesenjangan pembangunan nasional; dan

9. Memperkuat masyarakat desa sebagai subjek pembangunan. $^{2}$

10. Sedangkan asas-asas pengaturan Undang-undang Desa ini adalah:

11. Rekognisi, yaitu pengakuan terhadap hak asal usul;

12. Subsidiaritas, yaitu penetapan kewenangan berskala lokal dan pengambilan keputusan secara lokal untuk kepentingan masyarakat desa;

13. Keberagaman, yaitu pengakuan dan penghormatan terhadap sistem nilai yang berlaku di masyarakat desa, tetapi dengan tetap mengindahkan sistem nilai bersama dalam kehidupan berbangsa dan bernegara;

2 Fokusmedia, Himpunan Peraturan PerundangUndangan "Undang-Undang Desa, Kelurahan, dan Kecamatan”, Bandung, 2014, Hal 5.
14. Kebersamaan, yaitu semangat untuk berperan aktif dan bekerja sama dengan prinsip saling menghargai antara kelembagaan di tingkat desa dan unsur masyarakat desa dalam membangun desa;

15. Kegotongroyongan, yaitu kebiasaan saling tolong-menolong untuk membangun desa;

16. Kekeluargaan, yaitu kebiasaan warga masyarakat desa sebagai bagian dari satu kesatuan keluarga besar masyarakat desa;

17. Musyawarah, yaitu proses pengambilan keputusan yang menyangkut kepentingan masyarakat desa melalui diskusi dengan berbagai pihak yang berkepentingan;

18. Demokrasi, yaitu sistem pengorganisasian masyarakat desa dalam suatu sistem pemerintahan yang dilakukan oleh masyarakat desa atau dengan persetujuan masyarakat desa serta keluhuran harkat dan martabat manusia sebagai makhluk Tuhan Yang Maha Esa diakui, ditata, dan dijamin;

19. Kemandirian, yaitu suatu proses yang dilakukan oleh pemerintah desa dan masyarakat desa untuk melakukan suatu kegiatan dalam rangka memenuhi kebutuhannya dengan kemampuan sendiri;

20. Parsipasi, yaitu turut berperan aktif dalam suatu kegiatan;

21. Kesetaraan, yaitu kesamaan dalam kedudukan dan peran;

22. Pemberdayaan yaitu upaya peningkatan taraf hidup dan kesejahteraan masyarakat Desa melalui penetapan kebijakan, program, dan kegitan yang sesuai dengan esensi masalah dan prioritas kebutuhan masyarakat Desa; dan 
23. Berkelanjutan, yaitu suatu proses yang dilakukan secara terkoordinasi, terintegrasi, dan berkesinambungan dalam merencanakan dan melaksanakan program pembangunan Desa. $^{3}$

Desa masa depan dapat melakukan perubahan tata kelola penyelengaraan pemerintahan yang efektif melalui wewenang Desa, Kewenangan Desa mengatur dan mengurus kepentingan masyarakat Desa berdasarkan hak asal usul, pelaksanaan pembangunan yang berdaya guna, serta pembinaan masyarakat dan pemberdayaan masyarakat di wilayahnya. ${ }^{4}$ Kewenangan Desa tersebut meliputi:

a. Kewenangan berdasarkan hak asal usul;

b. Kewenangan lokal berskala Desa;

c. Kewenangan yang ditugaskan oleh Pemerintah, Pemerintah Daerah Provinsi, atau Pemerintah Daerah Kabupaten/Kota; dan

d. Kewenangan lain yang ditugaskan oleh Pemerintah, Pemerintah Daerah Provinsi, atau Pemerintah Daerah Kabupaten/Kota sesuai dengan ketentuan peraturan perundangundangan. ${ }^{5}$

Isu-isu yang muncul seputar dana yang akan dikucurkan untuk desa dampak dari disyahkannya Undang-undang Nomor 6 Tahun 2014 Tentang Desa 2014, jumlah yang sangat besar karena akan diambil

\footnotetext{
${ }^{3}$ Ibid, Fokusmedia, Hal 73

${ }^{4}$ Ibid, Yen Herizal

${ }^{5}$ Op. Cit, Fokusmedia, Hal 13.
}

prosentase tertentu dari Anggaran Pendapatan Belanja Negara (APBN) dan dari prosentase itu akan dibagikan kepada Pemerintahan Desa. Satu desa memperoleh alokasi dana 1 Milyar. Yang menjadi persoalan penelitian ini seberapa besar kerusakan, kekacauan, konflik kepentingan, dan berbagai persoalan lain yang tumbuh di desa akibat adanya uang 1 Milyar tersebut. Berbagai permasalahan tersebut bisa saja justru menjadi amat kontra-produktif dari bayangan semula tentang otonomi dan kesejahteraan untuk masyarakat Desa.

Berdasarkan uraian diatas, Persoalannya adalah Siapakah aktor-aktor yang diuntungkan di balik Undangundang Nomor 6 Tahun 2014 Tentang Desa?. Dan Potensi konflik apakah yang dimungkinkan timbul dengan ditetapkannya Undang-undang Nomor 6 Tahun 2014 Tentang Desa?.

\section{PEMBAHASAN}

\section{A. Aktor-aktor Yang Diuntungkan Dibalik Undang-undang Nomor 6 Tahun 2014 Tentang Desa}

Kelompok ini memainkan peran penting dalam pembentukan kebijakan. Kelompok-kelompok kepentingan menjalankan fungsi artikulasi kepentingan, yaitu mereka berfungsi menyatakan tuntutan-tuntutan dan memberikan alternatif-alternatif tindakan kebijakan. 
Selain itu, kelompok ini juga sering memberikan informasi yang bersifat teknis mengenai sifat serta konsekuensikonsekuensi yang mungkin timbul dari usul-usul kebijakan yang diajukan. Dengan demikian, kelompok kepentingan telah memberikan sumbangan yang berarti bagi rasionalitas pembentukan kebijakan. Satu hal yang harus diingat dalam mengkaji kelompok-kelompok kepentingan adalah bahwa kelompokkelompok yang diorganisasikan dengan baik pula dibandingkan dengan kelompokkelompok yang tidak diorganisasikan dengan baik. Pengaruh kelompok kepentingan terhadap keputusan kebijakan tergantung pada banyak faktor yang menyangkut ukuran-ukuran keanggotaan kelompok, keuangan dan sumber-sumber lain. Pengaruh kelompok kepentingan dalam pembuatan keputusan ditentukan pula oleh pandangan yang ditujukan terhadap kelompok tersebut. Suatu kelompok yang dianggap baik dan besar akan cenderung efektif dalam memengaruhi keputusan kebijakan dibandingkan dengan kelompok yang dipandang sebaliknya. Berdasarkan faktor-faktor yang telah disebutkan tadi?, Maka suatu kelompok kepentingan akan efektif memengaruhi keputusan kebijakan tertentu, namun mereka cenderung tidak efektif dalam memengaruhi bidang kebijakan yang lain. ${ }^{6}$ Misalnya Dalam sistem demokrasi, politisi dan partai-partai politik yang merupakan kelompok kepentingan memegang peran penting. Selain kelompok kepentingan juga ada para politisi menggunakan partai politik untuk meraih kekuasaan. Menurut Budi Winarno "dalam masyarakat modern, partai-partai politik seringkali melakukan "agregasi kepentingan". Partai-partai tersebut berusaha untuk mengubah tuntutan-tuntutan tertentu dari kelompokkelompok kepentingan menjadi alternatifalternatif kebijakan". ${ }^{7}$ Kelahiran Undangundang Nomor 6 Tahun 2014 Tentang Desa merupakan kristalisasi dari kehendak politik di parlemen yang hendak menghadapi pemilu Legislatif dan Pemilu Presiden 2014. Undang-undang Desa yang lahir ditahun politik, sangat mungkin menjadi komoditas politik, karena melalui Undang-undang desa partai-partai politik ingin meraup suara pemilih dipedesaan, sehingga tuntutan masyarakat dan aparatur desa dapat terakomodir didalamnya. Partai-partai bersaingan mencari simpati masyarakat di desa dengan mengkampanyekan bahwa Undangundang Desa adalah buah perjuangan

\footnotetext{
${ }^{6}$ Budi Winarno, Kebijakan Publik "Teori Proses dan Studi Kasus" CAPS (Center of Academic Publishing Service), Yogyakarta, Edisi Revisi, 2014. Hal 131-132.

${ }^{7}$ Ibid.
} 
partai-partai tersebut. Dan menjadi wajar kalau kemudian perangkat desa segera menuntut janji kampanye tersebut untuk diimplementasikan pada tahun $2015 .^{8}$ Seperti dana untuk desa sekitar Rp 1 miliar seperti yang diamanatkan dalam Undangundang Nomor 6 Tahun 2014 Tentang Desa dinilai bisa menjadi alat jualan untuk menarik simpati masyarakat pada Pemilihan Umum 2014. Menurut Pengamat Pemerintahan Universitas Hasanuddin, Adi Suryadi Culla di Makassar, Rabu (12/3/2014), seperti dikutip dari Antara. "Undang-undang itu bisa saja dijadikan jualan politik yang dimanfaatkan sejumlah oknum calon legislatif dan calon presiden untuk mencari simpati masyarakat pada Pemilu kali ini,". 9 Dalam hubungannya dengan kegiatan bernegara, peranan partai politik sebagai media dan wahana tentulah sangat menonjol. Di samping faktor-faktor yang lain seperti pers yang bebas dan peranan kelas menengah yang terarahkan dan sebagainya, peranan partai politik sangat menentukan dalam dinamika kegiatan bernegara. Partai politiklah yang bertindak sebagai perantara dalam proses-proses

\footnotetext{
${ }^{8}$ Ni'matul Huda, Hukum Pemerintahan Desa "Dalam Konstitusi Indonesia Sejak Kemerdekaan Hingga Era Reformasi”, Setara Perss, Malang 2015 Hal. 206.

${ }^{9}$ DanaDesaRp1MiliarJadi"JualanPolitik", http://nasional.kompas.com/read/2014/03/12/14551 39/Pengamat.Dana.Desa.Rp.1.Miliar.Jadi.Jualan.Po litik. Diakses pada tanggal 09 Agustus 2015.
}

pengambilan keputusan bernegara, yang menghubungkan antara warga negara dengan institusi-institusi kenegaraan. ${ }^{10}$ Pada umumnya, walaupun partai-partai politik ini mempunyai jangkauan yang lebih luas dibandingkan dengan kelompok-kelompok kepentingan, namun mereka lebih cenderung bertindak sebagai perantara dari pada sebagai pendukung kepentingan-kepentingan tertentu dalam pembentukan kebijakan. ${ }^{11}$

Besarnya

kewenangan Pemerintahan Desa dalam hal luas dan isi disatu pihak memberi peluang bagi upaya mendorong tumbuh dan berkembangnya otonomi desa, namun disisi lain bukan mustahil menjadi ancaman bagi perkembangan desa dimasa akan datang. Kewenangan desa yang luas ditunjang oleh sumber keuangan yang menjanjikan tampak seperti "pisau belati bermata dua". Dalam konteks Badan Permusyawarahan Desa (BPD) misalnya, sekalipun dinyatakan dalam Undang-undang Badan Permusyawarahan Desa berada diluar batasan pengertian Pemerintahan Desa, namun praktis Badan Permusyawarahan Desa (BPD) tak memiliki fungsi pengawasan terhadap akuntabilitas kepala desa. Kekuatiran tersebut bukan tanpa alasan, sebab pertanggungjawaban akhir

\footnotetext{
10 Jimly Asshiddiqie, Pengantar Ilmu Hukum Tata Negara, Rajawali Pers, PT. RajaGrafindo Persada, Jakarta, 2009. Hal. 403.

${ }^{11}$ Op. Cit, Budi Winarno.
} 
tahun anggaran dan akhir masa jabatan kepala desa disampaikan kepada Kepala Daerah, dan bukan kepada Badan Permusyawarahan Desa (BPD). Tugas Badan Permusyawarahan Desa (BPD) selain berfungsi sebagai lembaga pemerintahan hanya melakukan pembahasan dan menerima laporan dari masyarakat, tanpa kewenangan yang bersifat punishment. Kondisi semacam itu dapat melemahkan Badan Permusyawarahan Desa (BPD) sekaligus pada saat yang sama menguatkan Kepala Desa (executive heavy). Harus diakui bahwa batasan tentang Pemerintahan Desa disatu sisi memberi keleluasaan bagi Pemerintahan Desa dalam menjalankan program desa, namun disisi lain cenderung mengurangi chek and balance system sehingga Pemerintahan Desa berpeluang absen dari pengawasan wakil masyarakat. Luasnya kewenangan pemerintah desa tanpa pengawasan kuat Badan Permusyawaratan Desa (BPD) pada akhirnya membuka peluang korupsi di desa disebabkan sumber daya aparatur yang minim, apalagi jika pemerintah lalai dalam melakukan pembinaan dan pengawasan sebagaimana amanat Undang-undang desa. Secara logika pengelolaan otonomi desa yang menjanjikan semacam itu tanpa pembinaan lewat pendidikan dan pelatihan dalam pengelolaan keuangan desa justru dapat mendorong desa keruang tahanan kejaksaan. Peluang korupsi tidak saja terbuka lebar secara internal Pemerintahan Desa, demikian pula faktor eksternal berupa rent seeking Pemerintah Daerah. Diluar itu, potensi terjadinya korupsi secara sistemik dimungkinkan karena peluang seorang kepala desa dapat bertahan selama 6 kali 3 periode sehingga dengan mudah dapat melanggengkan kekuasaan lewat penggunaan sumber keuangan dan kewenangan yang luas. Semakin rendah pendidikan masyarakat semakin rendah pula daya kritis mereka terhadap pemerintah desa. Keadaan demikian akan memudahkan Pemerintahan Desa melakukan berbagai modus yang menguntungkan diri dan keluarga dekatnya. Kecenderungan demikian semakin sering terjadi pada sebagian besar desa yang tak cukup memiliki integritas moral dan derajat pendidikan yang memadai. Dalam banyak kasus Pemerintahan Desa seringkali bersekongkol atau berkolaborasi dengan Pemerintah Daerah untuk saling menutupi berbagai kelemahan pertanggungjawaban, sekaligus merawat hubungan patron clien dengan sejumlah pejabat yang bertanggungjawab dalam distribusi alokasi dana desa. Secara historis bakat feodalisme Pemerintahan Desa adalah produk kolonial yang cenderung lebih berorientasi pada kepentingan majikan/tuannya daripada kepentingan 
masyarakat. Kondisi demikian seringkali menjebak Pemerintahan Desa lupa diri hingga terciptanya oligarkhi, nepotisme, bahkan otoritarianisme Pemerintahan Desa. Terciptanya gejala demikian dimulai sejak era Raffles berkuasa (1811-1816), dimana sistem seleksi Kepala Desa tampak berjalan secara demokratis setelah melalui serangkaian manipulasi untuk kepentingan politik penjajah. Namun harus disadari bahwa pertumbuhan dan perkembangan demokrasi desa di Indonesia menurut Nurcholis tidaklah sama sebagaimana pertumbuhan dan perkembangan demokrasi di dunia barat. Perbedaan pendidikan dan kedewasaan politik masyarakat barat dan Indonesia mengakibatkan demokrasi di tingkat desa hingga dua ratus tahun lamanya tak menghasilkan demokrasi substansial, kecuali demokrasi prosedural. Inilah yang menjadi salah satu sebab mengapa desa tak dapat tumbuh dan berkembang dengan sehat meskipun mekanisme demokrasinya bekerja mendahului demokrasi langsung dewasa ini. Disisi lain, bersamaan dengan menguatnya kewenangan desa dan meningkatnya sumber-sumber keuangan desa dalam jangka panjang dapat mendorong peningkatan kuantitas desa kalau tidak perubahan status kelurahan menjadi desa dan desa adat. Tingginya diskresi dalam penataan desa dapat membuat sibuk pemerintah daerah dalam mengatur lalu lintas perubahan status jenis kelamin kelurahan menjadi desa atau desa adat, desa menjadi desa adat dan atau sebaliknya sesuai kebutuhan politik elite desa. Dengan pertimbangan pragmatis akan datangnya subsidi desa maka semangat memekarkan desa kemungkinan dapat menjadi trend dimasa mendatang. Realitas semacam ini cenderung melahirkan konflik horizontal dan vertikal di tingkat desa akibat lambatnya pembentukan desa serta sejumlah ketidakpuasan akibat kompetisi yang ketat dalam pemilihan kepala desa. Apalagi transisi dari status desa persiapan ke desa defenitif yang hanya membutuhkan usia 13 tahun, tentu saja bukan halangan berarti dalam memperbanyak desa baru atas nama kehendak masyarakat setempat. ${ }^{12}$ Dengan bersandar pada prinsip kewenangan yang luas ditambah sifat monopolistik tanpa akuntabilitas, maka pemerintah desa bukan mustahil dapat terjebak pada masalah kejahatan korupsi diluar konfrontasi yang akan semakin gaduh dengan masyarakat dilingkungan desa.

$>$ Pertama, aturan teknis harus mampu memperjelas hubungan kewenangan antara pemerintah desa dengan Badan Permusyawarahan Desa (BPD), Kecamatan, dan Pemerintah Daerah.

12 Muhadam Labolo, Dinamika Politik dan Pemerintahan Lokal, Ghalia Indonesia, Bogor, 2015, Hal 178-179. 
Menihilkan pengaturan soal hubungan kewenangan di antara entitas tersebut dapat mendorong konflik latent dalam jangka panjang.

Kedua, aturan teknis harus mendesain suatu mekanisme kontrol yang jelas untuk mencegah meningkatnya peluang korupsi di desa. Pengaturan harus memperjelas pertanggungjawaban

keuangan yang berasal dari sumber

Anggaran

Pendapatan Belanja Negara (APBN), Anggaran

Pendapatan Belanja Daerah (APBD) dan sumber lain yang dianggap sah. Jika tidak, akan banyak kepala desa dan perangkatnya yang akan berurusan dengan pihak berwajib, demikian pula konflik dengan masyarakat.

Ketiga, sekalipun mekanisme akuntabilitas akhir tahun anggaran dan akhir masa jabatan kepala desa dilakukan langsung kepada kepala daerah, namun mengingat banyaknya desa di setiap daerah maka secara teknis perlunya pendelegasian sebagian kewenangan kepala daerah kepada camat dalam hal pengawasan yang bersifat administratif. Dapat dipahami bahwa mekanisme ini bertujuan meringkas

pertanggungjawaban melalui hirarkhi birokrasi, namun efek lebih jauh dari mekanisme demikian memungkinkan kepala desa hanya di kontrol kepala daerah yang notabene secara politik relatif diuntungkan bagi kepentingan

mempertahankan dan memperluas kekuasaan. Pada sisi lain tanpa pendelegasian kewenangan untuk mengontrol Kepala Desa oleh kepala daerah kepada Camat, maka relasi antara Pemerintahan Desa dan Camat akan semakin memburuk.

$>$ Keempat, aturan teknis harus mampu menciptakan syarat yang ketat dalam pembentukan desa, termasuk upaya mengkonversi kelurahan menjadi desa untuk mencegah nafsu menggandakan desa sebanyak mungkin bagi kepentingan jangka pendek. Dampak lain adalah lembaga pemerintahan khusus seperti Mukim di Aceh dapat kehilangan pamor karena hilangnya perhatian desa (Keuchik) akibat transfer dana yang menimbulkan diskriminasi.

Kelima, aturan teknis harus dapat memperjelas masa depan desa persiapan yang setelah melewati 1-3 tahun dinyatakan tidak layak menjadi desa defenitif. 
Apakah harus dikembalikan ke masyarakat atau dapat diajukan kembali dalam waktu tertentu.

Keenam, aturan teknis harus dapat memperjelas status keanggotaan calon kepala desa maupun perangkat desa dalam organisasi partai politik, apakah boleh sebagai anggota tanpa menjadi pengurus, atau boleh kedua-duanya, atau mungkin tak boleh keduaduanya. Hal ini untuk mencegah politisasi desa bagi kepentingan politik praktis.

Ketujuh, aturan teknis harus dapat menjawab masa jabatan kepala desa secara berturut-turut atau tidak berturut-turut. Demikian pula yang pernah menjabat sebagai kepala desa di desa lain selama tiga periode apakah dapat mencalonkan lagi di desa lain.

$>$ Kedelapan, aturan teknis harus memberi batasan tentang kewenangan desa dalam kaitan dengan pengaturan kawasan khusus/strategis sehingga tak kontraproduktif dengan kebijakan pemerintah daerah.

Kesembilan, aturan teknis harus dapat memperjelas kewenangan lokal selain kewenangan berdasarkan asal-usul, dan kewenangan yang diperbantukan oleh
Pemerintah

Daerah, Provinsi, dan Pemerintah Pusat. Hal ini penting sebab kewenangan desa berskala lokal di setiap daerah sifat tidak seragam, bahkan mungkin tidak ada kecuali yang telah ada sebelumnya.

Kesepuluh, selain aturan teknis harus menjawab amanah undang-undang desa dalam bentuk peraturan pemerintah, juga diperlukan inventarisasi masalah yang telah terjadi atau mungkin akan terjadi dalam bentuk simulasi untuk mengantisipasi ketegangan yang akan muncul dikemudian hari.

Kesebelas, dalam kesadaran semacam itu diperlukan pendidikan dan pelatihan yang memadai secara terusmenerus kepada Pemerintahan Desa, Badan Permusyawarahan Desa (BPD) dan stakeholders terkait guna menyambut semua kejutan yang akan tiba di desa.

Akhirnya, suka atau tidak, ketika desa memiliki kewenangan yang luas, sumber keuangan yang menjanjikan, masa jabatan yang relatif lama, minimnya kontrol dari masyarakat dan supradesa, serta meningkatnya rangsangan pembentukan desa disamping kompetisi sumber daya, maka otonomi desa sekaligus demokrasi desa akan mengalami 
cobaan berat yang mungkin akan mendewasakannya, atau sekaligus mendegradasikannya ketitik nadir yang paling lemah. ${ }^{13}$

\section{B. Potensi Konflik Yang}

Dimungkinkan Timbul Dengan Ditetapkannya Undang-undang Nomor 6 Tahun 2014 Tentang

Desa

Kesejahteraan masyarakat desa kiranya menjadi orientasi pertama dan utama lahirnya Undang-undang Desa. Walaupun tak bisa ditampik, nuansa politik tak bisa dimungkiri. Pembangunan yang partisipatif dan otonom sudah mengemuka dari tahun 1950-an. Sentralisasi kekuasaan dinilai mereduksi kaidah dan prinsip pembangunan seutuhnya. Solusinya, desentralisasi pembangunan menjadi jawaban atas stagnasi pembangunan yang berorientasi pada pembangunan manusia. Konsekuensi logisnya adalah pelibatan masyarakat dalam setiap aspek pembangunan multak diperlukan. Partisipasi masyarakat menjadi kunci utama dan pertama dalam pembangunan desa ke depan. Banyak harapan terkait dengan diberlakukannya Undang-undang Nomor 6 Tahun 2014 Tentang Desa. Kesejahteraan masyarakat desa merupakan tujuan utama. Walaupun banyak pihak menilai bahwa Undangundang Nomor 6 Tahun 2014 Tentang ${ }^{13}$ Ibid.
Desa sebenarnya bukan menguntungkan masyarakat desa, tetapi para politisi. Di satu sisi penilaian sebagian kalangan memiliki keabsahan. Undang-undang Desa yang dinilai syarat politis tak bisa dihindari. Jangkar sosial dalam legitimasi politik para politisi dengan adanya Undang-undang Nomor 6 Tahun 2014 Tentang Desa menuai hasilnya pada Pemilihan Legislatif. Sementara Undangundang Nomor 6 Tahun 2014 Tentang Desa akan mengalami persoalan serius manakala kemampuan APBN dalam membiayai 73.000 desa seluruh Indonesia dengan batas maksimal Rp 1,4 miliar per desa itu tidak mencukupi. Alih-alih mempercepat kesejahteraan masyarakat desa, justru Undang-undang Nomor 6 Tahun 2014 Tentang Desa akan melahirkan konflik baru bagi sebagian masyarakat yang ada di desa, baik konflik manifes maupun konflik laten. Implikasi Undang-undang Nomor 6 Tahun 2014 Tentang Desa yang mengalokasikan anggaran Rp 1,4 miliar, itu menjadi pesona bagi masyarakat desa. Elite desa tentu tidak memiliki tafsir tunggal terhadap Undang-undang Desa. Aneka kepentingan tentu menjadi orientasi yang sulit diingkari. Dalam sistem demokrasi yang prsedural dan panggung partisipasi masyarakat yang kurang partisipatif akan menuai banyak persoalan. Demokrasi dan partisipasi lip service akan menjadi 
pertunjukan yang diperankan oleh segelintir elite desa. Masyarakat miskin hanya menjadi penoton yang kerapkali dijadikan dagangan. Hal ini bercermin terhadap proses terbentuknya berbagai organisasi masyarakat lokal. Elite desa baik struktural dan kultural tak bisa dilepaskan dan menjadi pemeran kunci dari berbagai aspek pembangunan. Masyarakat miskin tak kuasa menjadi aktor dalam setiap pembangunan, sehingga peran yang digunakan adalah keterlibatan semu tidak bisa dihindari. Hal ini terjadi karena, warga miskin seringkali terkooptasi oleh pemikirannya sendiri bahwa orang miskin tak perlu tahu menahu terkait pembangunan. Bahkan lebih tragis adalah proses peminggiran (segregasi) sosial yang dilakukan elite itu semakin menegaskan ketidakmampuan warga miskin untuk berkiprah dalam panggung pembangunan. Fakta di atas ini menemukan relevansinya manakala meminjam istilah Gabriel A. Almond dan Sidney Verba mengenai tipe budaya politik. Gabriel A. Almond dan Sidney Verba, (1996) menjelaskan mengenai tipe budaya politik.

$>$ Pertama, tipe budaya politik parokial (parochial political culture). Dalam hal ini masyarakat sangat rendah dan tidak mau tahu mengenai perubahan sistem politik yang ada. Pengetahuan masyarakat mengenai politik berimplikasi kepada sikap acuhnya kepada struktur politik yang ada. Dan pada gilirannya budaya tunduk terhadap elit yang dinilai memiliki pengetahuan lebih tak bisa dihindari. Lantas apa yang bisa diharapakan manakala budaya masyarakat dengan tingkat kesadaran dan partisipasinya sangat rendah, maka kasta politik tak bisa dihindari. Para elite akan menjadi mufassir terhadap persoalan dan kebutuhan masyarakat miskin yang sebenarnya, reduktif dan ahistoris yang akan terjadi.

$>$ Kedua, budaya politik subjek (subject political culture). Dalam budaya politik masyarakat tipe ini masyarakat sudah menggunakan letupan emosi untuk menilai sistem politik atau objek politik, sehingga tidak heran masyarakat dalam kategori ini bisa menilai, memilah dan memilih kualitas pemimpinnya. Iklan politik atau simbol-simbol politik seringkali dinilai sebagai produk citra yang sengaja dibangun untuk mengelabui masyarakat bahwa para politisi seolah-olah berpihak kepada warga miskin.

$>$ Ketiga, budaya politik partisipan (partisipant political culture). Inilah puncak tingkatan budaya politik masyarakat. Di mana masyarakat memiliki kesadaran dan pemahaman terhadap politik, dalam hal ini masyarakat sudah mampu melakukan evaluasi dan mengkritisi sistem politik dan kebijakan yang dilakukan oleh Negara. 
Jika melakukan pisau analisnya Almond dan Verba maka Undang-undang Nomor 6 Tahun 2014 Tentang Desa akan menjadi buaian mimpi dalam mewujudkan kesejahteraan masyarakat miskin yang ada di desa. Tengok saja pembangunan desa selama ini. Ketidakpedulian masyarakat terhadap pembangunan desa dengan anggaran Alokasi Dana Desa (ADD) menjadi miniatur bahwa partisipasi masyarakat desa terutama masyarakat miskin hanya kebohongan belaka. Tradisi feodalistik kerapkali di temui dalam kepemimpinan Pemerintahan Desa. Tak hanya itu, ragam persoalan akan dihadapi oleh pemeritahan dan warga desa. Dana Rp 1,4 miliar sebagai "mandat" Undangundang akan menuai konflik manakala dalam implementasinya dana tersebut meleset dengan harapan masyarakat maupun Pemerintahan Desa. Alokasi anggaran hanya menjadi lipstik para politisi tanpa memikirkan kemampuan anggaran yang ada. Dan pada gilirannya, harapan tidak sesuai dengan kenyataan yang ada. Di sinilah Robert Gurr (1970), seorang ilmuwan sosial, memberikan analisisnya akan lahirnya konflik dan kekerasan dengan menggunakan teori deprivasi relatif. Gurr menilai bahwa kekerasan muncul karena adanya deprivasi relatif yang dialami masyarakat sebagai perasaan kesenjangan antara nilai harapan (value expectation) dengan kapabilitas nilai (value capabilities) yang dimiliki seseorang. Nilai harapan (value expectation) adalah harapan akan kualitas hidup kehidupan sebagai hak untuk dinikmati. Sedangkan nilai kapabilitas (value capabilities) sebagai kondisi untuk mendapatkan harapan itu. Bahkan, Gurr meyakini bahwa ketidakpuasan deprivatif relatif akan melahirkan terjadinya berbagai aksi kekerasan massal. Karena semakin besar intensitas ketidakpuasan, semakin besar pula dorongan untuk melakukan kekerasan. Tampaknya Undang-undang Nomor 6 Tahun 2014 Tentang Desa sebagai angin segar bagi masyarakat desa untuk menikmati kualitas hidup dan kesejahteraan patut diapresiasi. Akan tetapi, jika harapan itu tidak sesuai kenyataan tentu apa yang dikhawatirkan oleh Gurr tidak bisa dihindari. Konflik vertikal antara pemerintahan desa terhadap pemerintahan yang ada di atasnya tidak bisa dihindari. Tuntutan disahkannya Undang-undang Nomor 6 Tahun 2014 Tentang Desa beberapa tahun yang lalu tidak seindah yang dibayangkan. Akan tetapi, menjadi harapan semua bahwa dana Rp1,4 miliar itu tidak hanya menjadi konsumsi politik dan dagangan para politisi. Dan tidak hanya sekedar normatif tertuang dalam Undang-undang Nomor 6 
Tahun 2014 Tentang Desa maupun Peraturan Pemerintah No 43 tahun 2014. ${ }^{14}$ Kesimpulan

Bila memang Pemerintah mempunyai komitment untuk mendudukkan desa sebagai bagian dari penyelenggaraan Pemerintahan dengan cara memberikan lebel "Pemerintahan Desa" maka diperlukan sebuah perubahan paradigma berfikir dalam melihat desa sebagai bagian dalam penyelenggaraan pemerintahan.

Paradigma berfikir yang penulis maksudkan adalah bahwa Setiap Pemerintah lainnya mulai dari Kecamatan, Kabupaten/Kota, Propinsi, Pemerintah Pusat harus memperhatikan desa secara utuh. Dalam arti utuh adalah adanya keseimbangan antara kewajiban-kewajiban yang harus dipikul oleh pemerintah desa dengan hakhak yang harus diterima oleh Pemerintahan Desa. Jangan lagi melihat Pemerintahan Desa dari sudut kewajiban belaka hanya sebagai alat pemerintah yang harus mensukseskan berbagai macam program pemerintah tanpa melihat dari sisi kemampuan dan dukungan

\footnotetext{
${ }^{14}$ Mengurai Konflik dalam UU Desa, Abdus Salam As'ad, S.Sos., M.Si, Askot CD Mandiri Kab. Madiun, Koorkot 09 Kota Madiun, OSP 6 Provinsi Jawa Timur, PNPM Mandiri Perkotaan, Madiun, 27 November 2014, www.p2kp.org/wartadetil.asp? Diakses tanggal 30 Juni 2015.
}

yang diterimanya. Banyak hal yang selama ini dilakukan oleh Pemerintahan Desa dalam rangka menjalankan roda pemerintahan terutama hal-hal yang berkaitan dengan sosialisasi berbagai macam program. Oleh karena itu sudah saatnya pula difikirkan kembali berbagai hal yang dapat dilakukan agar Pemerintah desa dapat berjalan sesuai dengan keinginan bersama yaitu pemerintahan yang dapat memecahkan berbagai persoalan atau masalah bagi masyarakatanya.

Sebuah perubahan menjadi desa mandiri jangan disalah artikan bahwa Pemerintah lainnya menjadi tidak bertanggungjawab untuk kelangsungan atas penyelenggaraan pemerintahan desa malah seharusnya pemerintah pusat mendorong dan membangkitkan semangat bagi Pemerintahan Desa untuk maju dan bangkit serta berbenah diri sehingga wajah pemerintahan desa memang dapat menjadi citra pemerintahan lainnya dimata masyarakat.

\section{REFERENSI:}

\section{BUKU:}

Asshiddiqie, Jimly, 2009, Pengantar Ilmu Hukum Tata Negara, Rajawali Pers, PT. RajaGrafindo Persada, Jakarta.

Huda, Ni'matul, 2015, Hukum Pemerintahan Desa "Dalam 
Konstitusi Indonesia Sejak

Kemerdekaan Hingga Era

Reformasi”, Setara Perss, Malang.

Labolo, Muhadam, 2015, Dinamika Politik dan Pemerintahan Lokal, Ghalia Indonesia, Bogor.

Winarno, Budi, 2014, Kebijakan Publik

"Teori Proses dan Studi Kasus"

CAPS (Center of Academic

Publishing Service), Edisi Revisi,

Yogyakarta.

\section{BUKU UNDANG - UNDANG:}

Fokusmedia, Himpunan Peraturan

Perundang-Undangan "Undangundang Desa, Kelurahan, dan Kecamatan", Bandung, 2014.

\section{WEB SITE:}

Dana Desa Rp 1 Miliar Jadi "Jualan

Politik",

http://nasional.kompas.com/read/201

4/03/12/1455139/Pengamat.Dana.De

sa.Rp.1.Miliar.Jadi.Jualan.Politik. 09

Agustus 2015.

Mengurai Konflik dalam UU Desa, Abdus

Salam As'ad, S.Sos., M.Si, Askot

CD Mandiri Kab. Madiun, Koorkot

09 Kota Madiun, OSP 6 Provinsi

Jawa Timur, PNPM Mandiri

Perkotaan, Madiun, 27 November

2014,

www.p2kp.org/wartadetil.asp?. 30

Juni 2015. 